Vol. 24, No. 1, Januari 2021, hlm. 11-19

p-ISSN: 1410-9344; e-ISSN: 2549-5631

WARTA LPM

\title{
Edukasi Konsumsi Buah dan Sayur Sebagai Strategi dalam Pencegahan Penyakit Tidak Menular pada Anak Sekolah Dasar
}

\author{
Umi Mahmudah, Endri Yuliati \\ Program Studi S1 Ilmu Gizi, Fakultas Ilmu Kesehatan \\ Universitas Respati Yogyakarta \\ email : mahmudah_umi@ymail.com
}

\begin{tabular}{l}
\hline \multicolumn{1}{c}{ Article Info } \\
\hline Submitted: 30 October 2019 \\
Revised: 27 November 2020 \\
Accepted: 9 May 2020 \\
Published: 12 December 2020 \\
Keywords: education, \\
knowledge, attitude, vegetable \\
fruit, elementary school children
\end{tabular}

Kata Kunci: edukasi, pengetahuan, sikap, buah sayur, anak SD

\begin{abstract}
Primary school children are one of the most vulnerable groups on nutrition. Nationally, overweight or obesity in children aged 5-12 years is still high at 18.8\%. The prevalence of nutritional status in Al-Firdaus Elementary School is normal nutritional status 68.14\%, $21.97 \%$ overweight, $15 \%$ obesity and $2.20 \%$ thin and very thin. Lack of consumption of fruits and vegetables is the 10th highest risk cause of mortality in the world. Consumption of fruits and vegetables can reduce the risk of micronutrient deficiencies and non-communicable diseases. Efforts to increase awareness of fruit and vegetable consumption are carried out by promoting nutrition through communication, information and education. Method for this activities done by educate about fruit and vegetable consumption which begins with a pretest of knowledge and attitudes and ends with a posttest of knowledge and attitude and consumption offruit salad together. Education was carried on elementary school children in class V at Al Firdaus Surakarta Elementary School with a total of 21 students. Education by using powerpoint media and material handouts. There is an increase in the average knowledge and attitudes regarding consumption of fruits and vegetables in elementary school children. This is due to education about consumption of fruits and vegetables. Based on statistical analysis it is known that there is no influence of fruit and vegetable consumption education on knowledge and attitudes in elementary school children.
\end{abstract}

Abstrak
Anak-anak sekolah dasar merupakan salah satu kelompok yang rawan
mengenai masalah gizi. Secara nasional masalah gemuk pada anak
usia 5 - 12 tahun masih tinggi yaitu $18,8 \%$. Prevalensi status gizi pada
anak sekolah dasar di SD Al-Firdaus yaitu status gizi normal $68,14 \%$,
gemuk $21,97 \%$, sangat gemuk $15 \%$ serta kurus dan sangat kurus
$2,20 \%$. Kurangnya konsumsi buah dan sayur merupakan penyebab
risiko ke-10 tertinggi dari angka kematian di dunia. Konsumsi


buah dan sayur dapat mengurangi risiko defisiensi zat gizi mikro dan serangan penyakit tidak menular. Upaya dalam meningkatkan kesadaran konsumsi buah dan sayuran dilakukan promosi gizi melalui komunikasi, informasi, dan edukasi. Adapun metode yang digunakan dalam kegiatan ini adalah edukasi mengenai konsumsi buah dan sayur yang diawali dengan pretest pengetahuan dan sikap mengenai konsumsi buah sayur dan diakhiri dengan post test pengetahuan dan sikap serta konsumsi salad buah bersama. Edukasi dilakukan pada anak sekolah dasar kelas V di SD Al Firdaus Surakarta dengan jumlah 21 siswa. Edukasi dilakukan dengan menggunakan media power point dan handout materi sebagai pegangan siswa. Setelah proses kegiatan berlangsung, terdapat peningkatan rata-rata pengetahuan dan sikap mengenai konsumsi buah dan sayur pada anak sekolah dasar. Hal ini disebabkan karena adanya edukasi mengenai konsumsi buah dan sayur. Berdasarkan analisis statistik diketahui bahwa tidak terdapat pengaruh edukasi konsumsi buah dan sayur terhadap pengetahuan dan sikap pada anak sekolah dasar.

\section{PENDAHULUAN}

Anak sekolah dasar (SD) merupakan salah satu kelompok yang rawan mengenai masalah gizi (Hapsari, 2011). Anak SD merupakan kelompok usia rawan yang perlu mendapatkan perhatian khusus bagi keluarga, karena pada usia ini anak sedang mengalami pertumbuhan pesat (growth spurt). Defisiensi gizi pada periode ini dapat menyebabkan terhambatnya pertumbuhan dan perkembangan anak (Arisman, 2008). Secara nasional masalah gemuk pada anak usia $5-12$ tahun masih tinggi yaitu 18,8\%, yang terdiri dari 10,8\% gemuk dan 8,8\% sangat gemuk (Riskesdas, 2013) meningkat dua kali lipat dibandingkan tahun 2010 (9,2\%) (Riskesdas, 2010).

Berdasarkan data laporan hasil pemantauan status gizi anak baru masuk sekolah di wilayah Puskesmas Kota Surakarta menggunakan cut of point IMT/U, disebutkan bahwa total keseluruhan persentase status gizi lebih gemuk pada tahun 2014 sebesar 11\%. Pada Sekolah Dasar Muhammadiyah 1 Ketelan Surakarta pada bulan Juli 2015, didapatkan hasil bahwa dari total siswa-siswi kelas 3, 4, dan 5 sebanyak 374 anak, yang status gizinya normal sebanyak 177 anak (47,3\%), status gizi kurus 4 anak $(1,06 \%)$, status gizi lebih sebanyak 69 anak $(18,4 \%)$ dan yang obesitas sebanyak124 anak (33,15\%). Berdasarkan penelitian Rahmawati \& Marfuah (2016) diketahui bahwa prevalensi status gizi pada anak sekolah dasar di SD Al-Firdaus yaitu status gizi normal $68,14 \%$, gemuk $21,97 \%$, sangat gemuk 15\%, serta kurus dan sangat kurus 2,20\%.

Indonesia berada dalam transisi epidemiologi, di satu sisi masih mengalami masalah gizi kurang, namun di sisi lain terjadi kegemukan dan peningkatan prevalensi penyakit tidak menular terkait gizi seperti Diabetes mellitus, hypertensi, jantung koroner, stroke (Global Nutrition Report, 2014). Salah satu penyebab kegemukan atau obesitas pada anak adalah konsumsi sayur dan buah yang masih rendah (Anggraeni, 2016). Kurangnya konsumsi buah dan sayur merupakan penyebab risiko ke10 tertinggi dari angka kematian di dunia (BMKG et al., 2017). Meningkatkan konsumsi buah dan sayur sampai 600gram/hari dapat mengurangi beban penyakit di seluruh dunia sebesar 1,8\%, penyakit jantung 31\%, stroke 19\%, kanker esophagus 20\%, dan kanker paru-paru $12 \%$ (Lock et al, 2005). Konsumsi buah dan sayur dapat mengurangi risiko defisiensi zat gizi mikro dan serangan penyakit tidak menular (BMKG et al., 2017; Lock et al., 2005). Konsumsi sayur dan buah yang cukup juga menurunkan risiko sulit buang air besar (BAB/sembelit) dan kegemukan. Hal ini menunjukkan bahwa konsumsi sayuran dan buah-buahan yang cukup berperan dalam pencegahan penyakit tidak menular kronik. Konsumsi sayuran dan buah-buahan yang cukup merupakan salah satu indikator sederhana gizi seimbang (Kemenkes, 2014). 
Sebagian besar penduduk Indonesia mengkonsumsi buah dan sayur sebanyak 173 g/hari, lebih kecil dari Angka Kecukupan Gizi (AKG) yang direkomendasikan yaitu sebesar $400 \mathrm{~g} / \mathrm{kapita} /$ hari. Konsumsi buah lebih sedikit dari pada konsumsi sayur yaitu 67g, sedangkan sayur sebesar 107g/kapita/hari. Pada tahun 2016, konsumsi buah dan sayur, setengah dari seluruh provinsi di Indonesia di bawah rata-rata konsumsi nasional (173g/kapita/ hari). Konsumsi buah dan sayur tertinggi terdapat di Provinsi Bali, Yogyakarta dan Sulawesi, sedangkan yang terendah Provinsi Nusa Tenggara Timur, Kalimantan Utara, dan Kalimantan Barat. Namun demikian, tidak ada provinsi yang memenuhi konsumsi buah dan sayur yang direkomendasikan (BMKG et al., 2016). Menurut Hermina \& Prihatini (2014) menunjukkan bahwa hampir semua penduduk Indonesia mengonsumsi sayur $(94,8 \%)$ namun hanya sedikit yang mengonsumsi buah $(33,2 \%)$. Rerata konsumsi sayur penduduk $70,0 \mathrm{~g} /$ orang/hari dan konsumsi buah 38,8g/orang/ hari. Total konsumsi buah dan sayur penduduk 108,8g/orang/hari. Bila dibandingkan dengan kecukupan yang dianjurkan menurut pedoman gizi seimbang, konsumsi buah dan sayur tersebut masih rendah. Sebanyak 97,1\% penduduk kurang mengonsumsi buah dan sayur.

Anak-anak biasanya kurang menyukai buah dan sayur. Hal ini dapat dikarenakan orang tua kurang terampil dalam penyajian makanan, terutama sayur dan buah. Demi kepraktisan, makanan yang tersaji cenderung sama, rasa makanannya yang kurang enak dan jenisnya tidak bervariasi. Perilaku ini bisa timbul karena orang tua sering pilih-pilih makanan atau makan sambil nonton TV. Perilaku makan itu akan ditiru oleh anak (Ekayanti, 2007). Upaya kegiatan dalam meningkatkan kesadaran konsumsi buah dan sayuran dilakukan promosi gizi melalui Komunikasi, Informasi, dan Edukasi (KIE) bagi keluarga, dan anak-anak (Kemenkes, 2016). Masih sangat rendahnya konsumsi buah dan sayur di masyarakat, diperlukan adanya kampanye "Makan Sayur dan Buah" dalam upaya mencapai Keluarga Sadar Gizi (KADARZI) terutama pada anak usia sekolah dan remaja sebagai penerus bangsa (Mudjianto et al., 2011). Dukungan dari orang tua dan guru mutlak diperlukan untuk menjamin ketersediaan buah dan sayur di tingkat rumah tangga dan meningkatkan pengetahuan serta motivasi anak dalam mengkonsumsi buah dan sayur (Bestari \& Pramono, 2014). Berdasarkan permasalahan di atas, maka program edukasi konsumsi buah dan sayur sebagai strategi dalam pencegahan penyakit tidak menular pada anak SD diharapkan mampu meningkatkan pengetahuan dan sikap anak SD mengenai konsumsi buah dan sayur, sehingga dengan meningkatnya pengetahuan dan sikap maka dapat meningkatkan konsumsi buah dan sayur.

\section{METODE}

SD Al Firdaus merupakan unit pendidikan sekolah dasar. Anak sekolah dasar merupakan kelompok yang rawan gizi, karena masih dalam masa pertumbuhan dan perkembangan. Berdasarkan penelitian Rahmawati \& Marfuah (2016) diketahui bahwa prevalensi status gizi pada anak sekolah dasar di SD Al-Firdaus Surakarta yaitu status gizi normal 68,14\%, gemuk $21,97 \%$, sangat gemuk $15 \%$ serta kurus dan sangat kurus 2,20\%. Masalah gizi yang ditemukan pada anak sekolah dasar di SD Al Firdaus adalah gizi lebih. Anak sekolah (6-12 tahun) yang mempunyai pengetahuan tentang manfaat sayuran masih rendah $(16,7 \%)$. Secara nasional masalah gemuk pada anak usia 5 - 12 tahun masih tinggi yaitu $18,8 \%$, yang terdiri dari $10,8 \%$ gemuk dan 8,8\% sangat gemuk. Kondisi ini menunjukkan bahwa anak usia sekolah sebagai kelompok usia muda sebagian besar kurang tahu manfaat buah dan sayur bagi tubuh (Sudirman et al., 2009). Salah satu penyebab kegemukan atau obesitas pada anak adalah konsumsi sayur dan buah yang masih rendah. Menurut Siagian (2017) ada hubungan konsumsi buah dan sayur dengan kejadian obesitas pada anak SD. Anak yang kurang mengkonsumsi sayur memiliki risiko obesitas sebesar 7x dan anak yang kurang mengkonsumsi buah memiliki risiko obesitas sebesar 13x.

Tim pengabdian masyarakat melakukan kampanye edukasi mengenai konsumsi buah dan sayur pada anak sekolah dasar di SD Al Firdaus Surakarta. Berikut merupakan enam langkah tahapan pelaksanaan pengabdian masyarakat berdasarkan permasalahan mitra. 
a. Melakukan perijinan di SD Al-Firdaus Surakarta.

b. Melakukan koordinasi terkait waktu pelaksanaan pengabdian masyarakat dengan Kepala Sekolah SD Al-Firdaus Surakarta.

c. Menyusun materi penyuluhan dalam bentuk power point.

d. Menyusun kuesioner data pengabdian masyarakat terkait buah dan sayur (data identitas anak, preferensi buah sayur, pengetahuan sikap mengenai buah sayur).

e. Melakukan kampanye edukasi mengenai buah dan sayur yang diawali dengan pretest pengetahuan dan sikap mengenai konsumsi buah sayur yang dilakukan pada anak kelas 5B sejumlah 21 siswa.

f. Melakukan evalusi penyuluhan post test pengetahuan dan sikap mengenai konsumsi buah sayur serta makan bersama salad buah.

Capaian keberhasilan kegiatan ini adalah peningkatan pengetahuan dan sikap mengenai konsumsi buah dan sayur pada anak sekolah yang mampu meningkatkan konsumsi buah dan sayur pada anak sekolah dasar.

\section{HASIL DAN PEMBAHASAN}

Al Firdaus berdiri sejak 17 Maret 1997 diawali dengan unit pendidikan di tingkat prasekolah di wilayah Surakarta, Jawa Tengah dan dilanjutkan dengan pendirian sekolah dasar dan sekolah menengah. Al Firdaus mengkombinasikan nilai-nilai Islam, Nasional, Global yang setiap mata pelajaran (knowledge) dihubungkan secara tema kolaborasi (concepts) melalui trans atau global context, di samping siswa memahami isi/konten materi pelajaran, siswa juga mampu mengkaitkan dengan hal lain secara luas serta mengembangkan keterampilan metacognitive (skills), berusaha mempunyai akhlak dan sikap pelajar yang berbudi tinggi (attitude) serta mengamalkan ilmu dan pengertiannya dalam aksi (action) baik di sekolah maupun di rumah sebagai hasil dari pembelajarannya.

Cita-cita Al Firdaus adalah mempersiapkan Islamic Global Citizen yang kuat dalam segi afektif, kognitif, dan psikomotor. Nilai-nilai internasional yang dibangun di Al Firdaus berdasarkan pada tiga unggulan, yaitu nature, culture, dan language dari kearifan lokal Indonesia. Berdasarkan hasil pengabdian, diketahui bahwa data karakteristik terdiri dari usia, jenis kelamin, dapat dilihat pada Tabel 1.

\section{a. Jenis Kelamin}

Distribusi responden berdasarkan jenis kelamin dapat dilihat pada Tabel 1.

Berdasarkan Tabel 1 diketahui bahwa jenis kelamin paling banyak yang mengikuti kegiatan penelitian ini sebagai responden adalah laki-laki dengan jumlah 14 orang $(66,7 \%)$, lebih dari separuh jumlah responden secara keseluruhan.

b. Usia

Distribusi karakteristik responden berdasarkan usia dapat dilihat pada Tabel 2.

Berdasarkan Tabel 2 diketahui bahwa usia paling banyak yang mengikuti kegiatan penelitian ini sebagai responden adalah usia 11 tahun dengan jumlah 11 orang $(52,4 \%)$, lebih dari separuh jumlah responden secara keseluruhan. Berdasarkan hasil Riskesdas tahun 2013, menyatakan di Indonesia pada kelompok usia 10 tahun ke atas kurang konsumsi sayur dan buah sangat tinggi yaitu 93,6 \% dari kebutuhannya sehari dan di Jawa Tengah pada kelompok usia 10 tahun ke atas kurang konsumsi sayur dan buah mencapai $91 \%$ dari kebutuhannya sehari.

Tabel 1. Data Karakteristik Berdasarkan Jenis Kelamin

\begin{tabular}{lcc}
\hline Jenis Kelamin & Frekuensi (n) & Persentase (\%) \\
\hline Laki-Laki & 14 & 66,7 \\
Perempuan & 7 & 33,3 \\
\hline Total & 21 & 100 \\
\hline
\end{tabular}

Tabel 2. Data Karakteristik Responden Berdasarkan Usia

\begin{tabular}{ccc}
\hline Usia (th) & Frekuensi (n) & Persentase (\%) \\
\hline 10 & 10 & 47,6 \\
11 & 11 & 52,4 \\
\hline Total & 21 & 100 \\
\hline
\end{tabular}


Menurut Nirmala (2012) anak usia sekolah 6 - 12 tahun perlu memperhatikan pola makan, karena pada usia ini anak sudah dapat memilih makanan yang disukai dan tidak disukai akibat pengaruh lingkungan. Oleh karena itu perlu pengawasan agar tidak salah dalam memilih makanan. Guillain et al. (2013) menyebutkan beberapa survei melaporkan konsumsi sayur dan buah pada remaja dan anak-anak kurang dari rekomendasi yang dianjurkan terutama pada sayur. Kebiasaan makan yang salah pada masa anak-anak dapat berlanjut dan menjadi bibit masalah kesehatan yang serius di usia dewasa.

c. Pengetahuan dan Sikap Sebelum dan Sesudah Intervensi

Pengukuran pengetahuan dan sikap dilakukan selama 2 kali, yaitu sebelum intervensi menggunakan media cakram dan sesudah intervensi menggunakan media cakram.

Berdasarkan Tabel 3 diketahui bahwa pengetahuan kategori baik sebelum dilakukan intervensi sebesar 11 orang $(52,4 \%)$, meningkat menjadi 15 orang $(71,4 \%)$ setelah dilakukan edukasi menggunakan media power point. Berbeda dengan variabel sikap. Sikap baik dan kurang baik pada sebelum dan sesudah dilakukan intervensi sama, yaitu sikap baik 15 orang $(71,4 \%)$ dan sikap kurang baik 6 orang $(28,6 \%)$.

Tabel 3. Analisis Pengetahuan dan Sikap

Sebelum dan Sesudah Intervensi

\begin{tabular}{lcccc}
\hline \multirow{2}{*}{ Variabel } & \multicolumn{2}{c}{ Pre Test } & \multicolumn{2}{c}{ Post Test } \\
\cline { 2 - 5 } & (n) & $(\%)$ & $(\mathrm{n})$ & $(\%)$ \\
\hline Pengetahuan & & & & \\
Baik & 11 & 52,4 & 15 & 71,4 \\
Kurang Baik & 10 & 47,6 & 6 & 28,6 \\
Total & 21 & 100 & 21 & 100 \\
\hline Sikap & & & & \\
Baik & 12 & 57,1 & 15 & 71,4 \\
Kurang Baik & 9 & 42,9 & 6 & 28,6 \\
Total & 21 & 100 & 21 & 100 \\
\hline
\end{tabular}

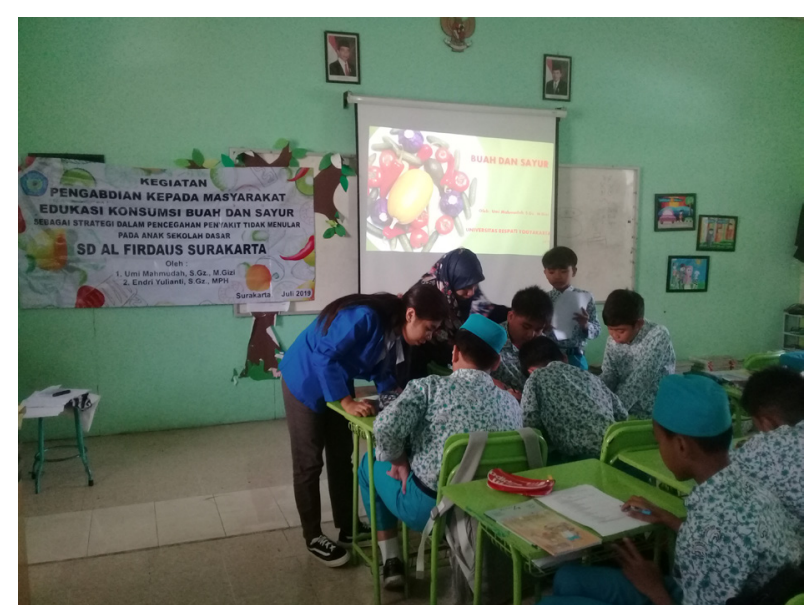

Gambar 1. Pengisian Kuesioner

d. Analisis Pengaruh Pengetahuan Sebelum dan Sesudah Dilakukan Edukasi

Analisis pengaruh pengetahuan sebelum dan sesudah dilakukan edukasi menggunakan media power point adalah menggunakan uji statistic parametric yaitu Paired T Test, hal ini dikarenakan data terdistribusi normal.

Dari Tabel 4 diketahui bahwa nilai minimum pengetahuan pretest 26,67 dan nilai minimum posttest 33,33 . Sedangkan nilai maksimum pretest adalah 86,67 dan nilai maksimum post test adalah 86,67. Terjadi peningkatan rata-rata nilai pengetahuan pretest dari 56,82 menjadi 64,76 setelah dilakukan edukasi gizi mengenai konsumsi buah dah sayur. Dari hasil uji statistik Paired T Test $p$ value pengetahuan diketahui bahwa $\mathrm{p}>0.05$ $(\mathrm{p}=0.061)$ sehingga dapat disimpulkan bahwa tidak ada perbedaan antara nilai pengetahuan pre test dan post test sehingga dapat disimpulkan bahwa tidak terdapat pengaruh edukasi mengenai konsumsi buah dan sayur sebagai strategi dalam pencegahan penyakit tidak menular.

Tabel 4. Uji Paired T Test Pengetahuan Sebelum dan Sesudah Edukasi

\begin{tabular}{lccccc}
\hline Pengetahuan & Min & Max & Mean & SD & p value \\
\hline pre test & 26.67 & 86.67 & 56.82 & 16.94 & 0.061 \\
post test & 33.33 & 100 & 64.76 & 20.01 & \\
\hline
\end{tabular}


Menurut Notoatmodjo (2003), pengetahuan gizi meliputi pengetahuan tentang pemilihan bahan makanan dan konsumsi sehari-hari dengan baik dan memberikan semua zat gizi yang dibutuhkan untuk fungsi normal tubuh. Pemilihan dan konsumsi bahan makanan berpengaruh terhadap status gizi seseorang. Pengetahuan gizi seseorang dapat diperoleh melalui penyuluhan (edukasi), media massa, elektronik, buku petunjuk, permainan dan kerabat dekat.

Salah satu upaya dalam memberikan pendidikan gizi pada anak adalah melalui media pendidikan sebagai alat bantu pendidikan dalam menyampaikan bahan pendidikan/ pengajaran. Manfaat penggunaan media pendidikan adalah mencapai sasaran yang lebih banyak menimbulkan minat sasaran pendidikan, memotivasi sasaran pendidikan untuk melaksanakan pesan-pesan kesehatan, membantu mengatasi berbagai hambatan dan membantu sasaran pendidikan untuk belajar lebih cepat dan lebih banyak (Notoatmodjo, 2003).

Pemberian informasi kepada siswa mengenai kebutuhan zat gizi dalam sehari perlu diinformasikan sejak dini agar siswa menyadari pentingnya sumber zat gizi bagi tubuh dan menerapkannya dalam kehidupan sehari-hari. Anggapan anak bahwa makanan sumber serat sangat tidak enak dan membosankan berubah menjadi makanan sumber serat adalah jenis makanan yang tidak hanya menyehatkan, tetapi juga memiliki rasa yang enak dan lezat.

Berdasarkan hasil kegiatan pengabdian, diketahui bahwa pada saat sebelum dilakukan edukasi buah dan sayur (pre test) pengetahuan baik sebesar 11 orang (52.4\%) dan pengetahuan kurang baiksebesar 10 orang (47.6\%). Pengetahuan baik meningkat menjadi 15 orang $(71.4 \%)$ dan pengetahuan kurang baik menurun menjadi 6 orang (28.6) setelah dilakukan edukasi konsumsi buah dan sayur (post test) menggunakan media powerpoint. Hal ini dibuktikan dengan adanya peningkatan nilai maksimum dari 86.67 pada saat pretest menjadi 100 pada saat post test.

Meningkatnya pengetahuan ini diharapkan dapat mengubah sikap dan tindakan yang lebih baik dalam mendorong anak-anaknya untuk mengkonsumsi buah dan sayur. Hal ini sejalan dengan penelitian Bordheauduij et al. (2008) dan Fibrihirzani (2012) yang menemukan bahwa pengetahuan gizi anak usia sekolah berhubungan signifikan dengan konsumsi buah dan sayur.

Berdasarkan hasil uji statistic diketahui bahwa terdapat peningkatan rata-rata pengetahuan sebelum dan sesudah dilakukan edukasi konsumsi buah dan sayur dari 56.82 menjadi 64.76. Berdasarkan uji Paired T Test diketahui bahwa p value $0.061(\mathrm{p}>0.05)$ hal ini menunjukkan bahwa tidak ada perbedaan antara nilai pengetahuan pre test dan post test sehingga dapat disimpulkan tidak terdapat pengaruh pengetahuan sebelum dan sesudah dilakukan edukasi mengenai konsumsi buah dan sayur sebagai strategi dalam pencegahan penyakit tidak menular. Hal ini kemungkinan disebabkan oleh pemilihan media yang kurang tepat atau siswa merasa bosan sehingga materi yang diberikan kurang diserap dengan baik oleh siswa. Berbeda dengan hasil pengabdian Ichsan et al (2015) bahwa terdapat peningkatan pengetahuan dan terdapat perbedaan yang bermakna antara pengetahuan sebelum dan setelah penyuluhan tentang pentingnya sayuran pada anak-anak TK dengan menggunakan media powerpoint. Meningkatnya pengetahuan ini diharapkan dapat mengubah sikap dan tindakan yang lebih baik dalam mendorong anak-anaknya untuk mengkonsumsi sayuran dalam menu sehari-hari.

Dan hasil penelitian Kusumarani et al (2018) bahwa terdapat perbedaan pada peningkatan pengetahuan mengenai buah dan sayur pada kelompok yang diberi perlakuan menggunakan media komik. Serta penelitian Utami (2017) menunjukkan bahwa ada pengaruh penyuluhan dengan metode ceramah dan media poster terhadap perubahan pengetahuan anak mengenai buah dan sayur di sekolah dasar 126 dan 115 Palembang. Penelitian 
Azadirachta \& Sumarni (2017) pendidikan gizi menggunakan media buku saku mampu meningkatkan pengetahuan dan praktik siswa mengenai konsumsi buah dan sayur pada siswa sekolah dasar.

Pengetahuan gizi berperan dalam memberikan cara memilih pangan dengan baik sehingga dapat mencapai keadaan gizi yang cukup. Tingkat pengetahuan yang menentukan perilaku konsumsi pangan salah satunya didapat melalui jalur pendidikan gizi yang umumnya dipndang lebih baik diberikan sedini mungkin untuk menambah pengetahuan dan memperbaiki konsumsi pangan (Suhardjo, 2003).

Berbagai kajian menunjukkan bahwa konsumsi sayur dan buah yang cukup turut berperan dalam menjaga kenormalan tekanan darah, kadar gula, dan kolesterol darah. Hal ini menunjukkan bahwa konsumsi sayur dan buah yang cukup turut berperan dalam pencegahan penyakit tidak menular (Kemenkes, 2014). Berbagai penelitian tentang peran sayur dan buah sebagai sumber serat membuktikan bahwa serat dapat mencegah penyakit jantung dan kanker serta memberikan efek protektif terhadap kejadian stroke, penyakit katarak, penyakit paru-paru obstruktif kronik, dan hipertensi. Pola makan yang buruk yang dikombinasi dengan perilaku tidak sehat seperti gaya hidup sedentary, berkontribusi pada kejadian overweight dan obesitas bukan hanya pada orang dewasa, tetapi juga pada anak-anak dan remaja (Mc Aleese, 2007).

e. Pengaruh Sikap Sebelum dan Sesudah Dilakukan Edukasi

Analisis pengaruh sikap sebelum dan sesudah dilakukan edukasi menggunakan media cakram gizi menggunakan uji statistic parametric yaitu Uji Paired T Test, hal ini dikarenakan data terdistribusi normal.

Dari Tabel 5 menunjukkan bahwa tidak ada perbedaan sikap antara pre test dan post test sehingga dapat disimpulkan bahwa tidak terdapat pengaruh edukasi konsumsi buah dan sayur menggunakan media powerpoint.
Tabel 5. Sikap Sebelum dan Sesudah Dilakukan Intervensi

\begin{tabular}{ccccc}
\hline Sikap & SD & Correlation & Mean & p value \\
\hline pre test & 4.085 & 0.610 & 31.90 & 0.523 \\
post test & 4.27 & & 32.42 & \\
\hline
\end{tabular}

Sikap merupakan suatu reaksi atau respon seseorang terhadap suatu stimulus atau objek (Notoatmodjo, 2003). Berdasarkan hasil kegiatan pengabdian, diketahui bahwa pada saat sebelum dilakukan edukasi buah dan sayur (pre test) sikap baik sebesar 12 orang (57.1\%) dan sikap kurang baik sebesar 9 orang (42.9\%). Sikap baik meningkat menjadi 15 orang (71.4\%) dan sikap kurang baik menurun menjadi 6 orang (28.6) setelah dilakukan edukasi konsumsi buah dan sayur (post test) menggunakan media powerpoint. Hal ini dibuktikan dengan adanya peningkatan rata-rata sikap dari 31.90 pada saat pretest menjadi 32.42 pada saat post test.

Berdasarkan uji Paired T Test diketahui bahwa $p$ value $0.523(p>0.05)$ hal ini menunjukkan bahwa tidak ada perbedaan antara sikap pretest dan post test sehingga dapat disimpulkan tidak terdapat pengaruh sikap sebelum dan sesudah dilakukan edukasi mengenai konsumsi buah dan sayur sebagai strategi dalam pencegahan penyakit tidak menular. Hal ini dikarenakan banyak faktor yang mempengaruhi perubahan sikap.

Untuk merubah sikap tidaklah mudah dan membutuhkan waktu yang cukup lama, karena sikap dapat terbentuk dari 3 komponen yaitu kognitif, afektif dan kecenderungan tindakan (konatif) yang merupakan suatu sistem, sehingga tidak dapat dilepas satu dengan lainnya. Hal ini sejalan dengan penelitian Kusumarani et al (2018) tidak ada perbedaan pada peningkatan sikap mengenai buah dan sayur pada kelompok yang diberi perlakuan menggunakan media komik. 


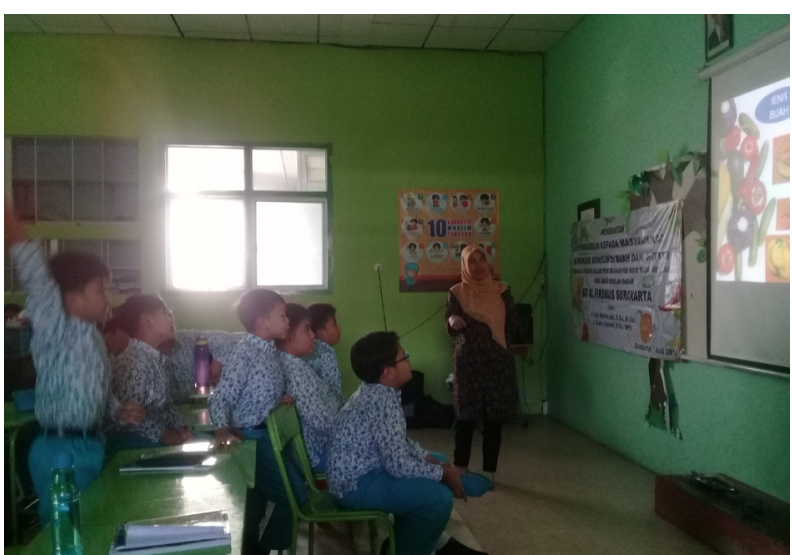

Gambar 2. Pemberian edukasi

Suatu kebiasaan makan sayur dan buah yang teratur dalam keluarga akan membentuk kebiasaan yang baik bagi anak-anak. Selanjutnya pola makan dalam keluarga juga harus diperhatikan, frekuensi makan bersama keluarga, ketersediaan buah dan sayur di rumah, membiasakan makan buah-buahan dan sayuran, orang tua memberikan contoh makan buah dan sayur pada anak, dapat membentuk kebiasaan bagi anak-anak.

\section{SIMPULAN}

Berdasarkan hasil kegiatan pengabdian dapat disimpulkan bahwa terdapat peningkatan rata-rata pengetahuan dan sikap mengenai konsumsi buah dan sayur pada anak sekolah dasar setelah diberikan edukasi mengenai konsumsi buah dan sayur menggunakan media powerpoint dan handout. Adanya kegiatan edukasi secara rutin dan berkesinambungan untuk meningkatkan konsumsi buah dan sayur pada anak sekolah dasar sebagai strategi dalam pencegahan penyakit tidak menular.

\section{UCAPAN TERIMA KASIH}

Dalam pelaksanaan kegiatan pengabdian ini, kami tidak lepas dari bantuan dan bimbingan beberapa pihak. Ucapan terima kasih kami sampaikan kepada PPPM Universitas Respati Yogyakarta yang telah memberikan dana hibah internal dengan nomor kontrak 11/PKM/Int/ PPPM/IV/2019. Terima kasih kepada Ibu kepala sekolah, karyawan, dan segenap ibu guru SD Al Firdaus Surakarta yang memberikan ijin dan membantu suksesnya kegiatan ini.

\section{DAFTAR PUSTAKA}

Anggraeni, A,S. (2016). Correlation between Consumption Pattern of Fruit and Vegetables with Risk of Obesity in Scholl-Age Children. Skripsi: Tidak dipublikasikan. UNAIR.

Azadirachta, F, L. \& Sumarni, S. (2017). Pendidikan Gizi Menggunakan Media Buku Saku Meningkatkan Pengetahuan dan Praktik Konsumsi Sayur dan Buah pada Siswa Sekolah Dasar. Media Gizi Indonesia, 12 (2), 107-115.

Arisman. (2008). Buku Ajar Ilmu Gizi:Gizi dalam Daur Kehidupan. Jakarta: Penerbit Buku Kedokteran EGC.

Bestari, G,S. \& Pramono, A. (2014). Pengaruh Edukasi Gizi Menggunakan Media Buku Cerita Bergambar Terhadap Perubahan Konsumsi Buah dan Sayur Anak Di PAUD Cemara Semarang. Journal of Nutrition College, 3(4).

Bourdeaudhuij ID, Velde St, Brug J, Due P, Wind M, Sandvik C, Maes L, Wolf A, Rodrigo CP, Yngve A et al. 2008. Personal, Social, and Environmental Predictors Of Daily Fruit And Vegetable Intake In 11-Year-Old Children In Nine European Countries. Eur J Clin Nutr. 62: 834-841.

BMKG., KEMENTAN., FAO., BNPB., LAPAN. (2017). Buletin Pemantauan Ketahanan Pangan Indonesia. Fokus Khusus: Tren konsumsi dan produksi buah dan sayur. Volume 8.

Fibrihirzani H. 2012. Hubungan Antara Karakteristik Individu, Orang Tua, dan Lingkungan dengan Konsumsi Buah dan Sayur pada Siswa. Skripsi FKM UI

Global Nutrition Report. Acount and Accountability to Accelerate The World's Progress on Nutrition. International Food Policy Research Institut. (2014). Available from: www.ifri.org/ publication/ global-nutrition-report-2014-andaccountibility-accelerate-words-progress. 
Guillain BL, Jones L, Oliveira A, Moschonis G, Beteko A, Lopes C, Moreira P, Manios Y, Papadopoulos NG, \& Emmett P et al. (2013). The Influence of Early Feeding Practices on Fruit and Vegetable Intake among Preschool Children in 4 European Birth Cohorts1-3. American Journal of Clinical Nutrition, doi:10.3945/ajcn.112.057026.

Hapsari I.A., Putu YA, Luh SA. (2011) Gambaran Status Gizi Siswa SD Negeri 3 Peliatan Kecamatan Ubud, Kabupaten Gianyar. Denpasar: Fakultas Kedokteran Universitas Udayana; Available from: http://ojs.unud.ac.id/ index.php/eum/article/download/6695/5104.

Hermina \& Prihatini, S. (2016) . Gambaran Konsumsi Sayur dan Buah Penduduk Indonesia dalam Konteks Gizi Seimbang: Analisis Lanjut Survei Konsumsi Makanan Individu (SKMI) 2014. Buletin Penelitian Kesehatan, 44(3), 205 - 218.

Ichsan, B., Wibowo, B,H., Sidiq, M,N. (2015). Penyuluhan Pentingnya Sayuran Bagi Anak-Anak Di Tkaisyiyah Kwadungan, Trowangsan, Malangjiwan, Colomadu, Karanganyar, Jawatengah. WARTA LPM, 18 (1). ISSN 1410 - 9344.

Kemenkes. (2014). Pedoman Gizi Seimbang. Kementrian Kesehatan Indonesia.

Kementerian Kesehatan RI. (2016). Buku Panduan Gerakan Masyarakat Hidup Sehat (GERMAS). Jakarta: Kementerian Kesehatan RI.

Kusumarani, A., Noviardhi, A., Susiloretni, K,A., Setiadi, Y. (2018). Pengaruh Media Komik Terhadap Pengetahuan Dan Sikap Tentang Sayur Dan Buah Di SDAisyiyah Dan SDN Kalicilik 2 Demak. ResearchGate.

McAllese JD, L.L Rankin. (2007). Research and Profes-sional Briefs: Garden-Based Nutrition Education Affect Fruit and Vegetable Consumption in Sixth-Grade Adolescents, J Am Diet Assoc, [online], No. 107 P.662-665. Dari: http://oahuces.hawaii. edu/ FVMM/forms/Garden-Based.pdf.

Mudjianto T, Jahari AB, Sri Prihatini, Hermina, Afriansyah N dan Hidayat TS. Uji Coba Media dan Identifikasi Saluran Edukasi dalam Rangka Pengembangan Strategi Edukasi Kadarzi. Tahun kedua: (2011). Laporan Penelitian. Bogor : Badan Penelitian dan Pengembangan Kesehatan.

Nirmala, D. (2012). Gizi Anak Sekolah. Jakarta : Kompas.

Notoatmodjo. (2003). Pendidikan dan Perilaku Kesehatan, Jakarta: Rineka Cipta.

Rahmawati, T \& Marfuah, D. (2016) Gambaran Status Gizi Pada Anak Sekolah Dasar. PROFESI 14(1), September 2016.

RISKESDAS. (2013). Riset Kesehatan Dasar. Jakarta: Badan Penelitian dan Pengembangan Kesehatan Departemen Kesehatan Republik Indonesia.

RISKESDAS. (2010). Riset Kesehatan Dasar. Tim Badan Penelitian dan Pengembangan Kesehatan Kementrian RI. Jakarta.

Siagian, D. (2017). Hubungan Konsumsi Sayur dan Buah dengan Obesitas pada Anak SD Kelas IV-VI Di SD Pantekosta Magelang. Naskah Publikasi. Yogyakarta : Politeknik Kementrian Kesehatan.

Sudiman H, Jahari AB, Tjukarni T, Prihatini S, Rosmalina Y, Latinulu S. et al. (2009.) Studi Pengembangan Strategi untuk Keberhasilan Keluarga Gizi (Kadarzi): Situasi Pelaksanaan dan Pengembangan Alternatif Indikator Kadarzi. Laporan Penelitian. Bogor : Badan Penelitian dan Pengembangan Kesehatan.

Suhardjo. (2003). Berbagai Cara Pendidikan Gizi. Jakarta: PT. Bumi Aksara.

Utami, D, P. (2017). Pengaruh Penyuluhan Buah-Buahan Dan Sayur-Sayuran Terhadap Pengetahuan Anak Sekolah Dasar Negeri 115 Dan 126 Palembang Tahun 2017. Politeknik Kesehatan Palembang. Kementerian Kesehatan Republik Indonesia. 